\title{
CONSERVATION OF MADAGASCAR'S GRANITE OUTCROP ORCHIDS: THE INFLUENCE OF FIRE AND MOISTURE ${ }^{1}$
}

\author{
Melissa Whitman ${ }^{1,5}$, Michael MedleR ${ }^{2}$, Jean Jacques Randriamanindry ${ }^{3}$ \\ $\&$ ELISABETH RABAKONANDRIANINA ${ }^{4}$
}

\author{
${ }^{1}$ School of Biological Sciences, University of Nebraska, 208 Manter Hall, Lincoln, Nebraska 68588, U.S.A. \\ ${ }^{2}$ Huxley College of the Environment, Western Washington University, 516 High Street, Bellingham, \\ Washington, 98225, U.S.A. \\ ${ }^{3}$ BP 1571, Antananarivo 101, Madagascar. \\ ${ }^{4}$ Département de Biologie et Ecologie Végetale. Faculté des Sciences, \\ Université d'Antananarivo: BP 906, Antananarivo 101, Madagascar \\ ${ }^{5}$ Corresponding author: islandevolution@gmail.com
}

\begin{abstract}
Is there a difference in response to disturbance, or resource limitation, by similar taxa based on micro-site habitat heterogeneity? For this study we examined how fire and moisture availability influences the distribution of terrestrial and lithophytic orchids specific to Madagascar's granite outcrops (inselbergs). We compared orchid density in an area with a complex mosaic of burned and non-burned vegetation patches (three years after the event). Lithophytic species (subtribe Angraecinae) were sensitive to fire, but tolerant of limited moisture availability, and had a uniform distribution pattern associated with vegetation mat size. In contrast, most terrestrial species (subtribe Habenariinae) were not impacted by fire, but were limited to slopes with high water seepage, and had a clumped distribution pattern. The results suggest varying ecological niches between orchid subtribes, and among species, occurring on shared substrate. Within the larger area, we also compared three inselbergs with different fire disturbance history. One site with potential for lightning based fires, but absence of anthropogenic fires, had the greatest diversity (subtribes, genera, and species) of orchids and the highest occurrence of species restricted to a single site. For land management purposes it is inappropriate to assume that inselberg specific orchids will have the same response to environmental stressors. Angraecinae orchids are especially at risk from human associated fire disturbance and should be regarded as indicators for future conservation efforts.
\end{abstract}

RESUMÉ. Quelle est la réponse aux perturbations, et la limitation de l'humidité, par des taxons similaires basés sur l'hétérogénéité des micro-site de l'habitat? Pour cette étude nous avons examiné comment la disponibilité de feu et de l'humidité influence la répartition des orchidées endémiques malgaches spécifique des affleurements de granit (inselbergs). Trois ans après le passage du feu, nous avons compare les modes de distribution et l'abondance d'orchidées dans un habitat d'une mosaïque complexe de brûlures, en tenant compte de la densité par rapport à l'intensité des dégâts d'incendie et de la disponibilité de l'humidité. Les espèces du soustribu Angraecinae ont été sensibles au feu, mais tolérant à une disponibilité limitée de l'humidité. orchidées Angraecinae avait un modèle uniforme de la distribution influencée par la taille du tapis de végétation. Les espèces de la sous-tribu Habenariae étaient tolérants de feu, mais limitée aux pentes rocheuses humides par des écoulements d'eau. Habenariae ont été randomizes regroupés en masses compactes, influencée par des facteurs non encore identifiés. Les résultats suggèrent l'existence de différentes stratégies de survie des espèces. Il serait inexact de penser que les orchidées voisins sur un substrat de granite aurait la même réponse à des facteurs environnementaux ou de perturbation. orchidées Angraecoid sur les inselbergs sont exposés à des menaces spécifiques et doivent être considérées comme des espèces indicatrices de la conservation est prioritaire à l'avenir.

Key Words / Mots-CLÉs: conservation; inselberg de granit; Le Madagascar; Orchidaceae; Angraecinae; Habenariinae 
Introduction. Madagascar is considered to be an international conservation priority area because of the high concentration of endemism and biodiversity threatened with extinction (Bosser et al. 1996, Barthlott \& Porembski 1998, Du Puy \& Moat 1998, Myers et al. 2000). The majority of conservation efforts to date have focused on evergreen humid forests, or deciduous, seasonally dry forests (Bosser et al. 1996, Du Puy \& Moat 1998), rather than granite outcrops known as inselbergs - a habitat noted for unique flora that includes orchids, succulents, carnivorous, and desiccant tolerant species (Bosser et al. 1996, Barthlott \& Porembski 1998, Fischer \& Theisen 2000, Porembski $\&$ Barthlott 2000). The lack of inselberg protection is in part explained by the difficulty in identifying priority habitat at the landscape scale (based on vegetation type and subtle habitat characteristics) using satellite imagery (Du Puy \& Moat 1998). There is also less social incentive to protect inselbergs because of the absence of charismatic species (such as lemurs) that appeal to ecotourism and environmental organizations (Leader-Williams \& Dublin 2000), however recent multi-taxa analyses recognize the conservation importance of sites that were previously neglected such as habitat with sparse forest cover (ie central plateau massifs) or smaller sized forest remnants (Bosser et al. 1996, Kremen et al. 2008). A different challenge with managing, and maintaining, inselberg biodiversity is due to the limited number of ecological studies available (Barthlott \& Porembski 1998, Fischer \& Theisen 2000, Porembski \& Barthlott 2000), especially those that investigate the role of disturbance on plant communities specific to this habitat type (Bosser et al. 1996, Porembski et al. 2000, Yates et al. 2003).

Fire is one of the most common forms of habitat disturbance within Madagascar and is primarily associated with human activities rather than lightning (Bloesch 1999, Kull 2000). Culturally, fire is used for agriculture, cattle grazing, deforestation, and even as form of political protest (Bloesch 1999, Kull 2000, Kull 2002, Klein 2004). Restriction of human based fires is often at odds with the interests of villagers, except in instances where the local belief systems (ie taboos against burning holy sites) either directly or indirectly benefits conservation efforts (Bloesch 1999, Klein 2004). Even though fire has been a part of the Malagasy landscape for many generations, there is still much debate about the impact of fire disturbance on native habitat and the appropriate fire management approach for the future (Bloesch 1999, Kull 2000, Kull 2002, Klien 2004, Raxworthy \& Nussbaum 2006). Some scientific studies estimate that deforestation accounts for the rapid loss of $40 \%$ to $80 \%$ of Madagascar's original forest cover (Du Puy \& Moat 1998, Harper et al. 2007), while other studies indicate that habitat destruction has been grossly overestimated (Kull 2000, Kull 2002, Klein 2004).

The historic landscape of the highlands of Madagascar was most likely a non-continuous mix of schlerophyllous forest, shrubland, and montane heathland with seasonal fires associated with lightning (Raxworthy \& Nussbaum 1996, Bloesch 2002, Burney et al. 2003). The introduction of human set fires, extinction of megafauna, and the spread of livestock grazing dramatically changed the fire regime; fire intensity and frequency increased and resulted in the emergence of homogenous prairie grasslands as the dominant vegetation type (Bosser et al. 1996, Raxworthy \& Nussbaum 1996, Du Puy \& Moat 1998, Bloesch 1999, Fischer \& Theisen 2000, Bloesch 2002, Burney et al. 2003). The conversion of mountain forest to grassland is considered to be nearly irreversible (Bloesch 1999). Within Madagascar, inselbergs have been described as naturally protected against fire with the bare rock around their base that acts a barrier to inhibit the spread of fire from adjacent locations (Nilsson \& Rabakonandrianina 1988). The assessment of inselbergs as refuge for fire sensitive species in a fire prone landscape is consistent with observations of rock outcrops in Australia (Hopper 2000, Clarke 2002). This observation does not exclude potential lightning based fires from occurring; other studies have noted extensive fires from this ignition source (Yates et al. 2003). However high elevation areas, or other habitat with sparse or stunted vegetation (ie inselbergs), have a reduced fuel capacity that tends to result in lower intensity fires restricted to patches (Bloesch 2002) in contrast to dynamics of fires in dense forests (Clarke 2002).

We addressed this ecological knowledge gap by examining the impact of fire disturbance, and moisture availability, on flora specific to inselbergs of Madagascar. Orchids were used as indicator species of this habitat type because of the complexity of their 
ecological relationships and high levels of endemism (Nilsson \& Rabakonandrianina 1988, Nilsson et al. 1992, Pettersson \& Nilsson 1993, Jacquemyn et al. 2005, Linder et al. 2005). We also recognized the lack of ecological research on Malagasy orchids, aside from those related to evolution or pollination biology (Bosser et al. 1996). For the first portion of the study we included a general examination of orchid biodiversity and fire history of the Mt. Angavokely area, followed by a comparison of species occurrence and turnover within, and between, three inselbergs. We then performed a more in-depth analysis of orchid abundance on the inselberg that was most recently burned. Overall we determined that some endemic orchid species were highly sensitive to fire disturbance, while others were more influenced by moisture availability, in an area with high micro-site habitat heterogeneity.

\section{Methods}

Site Description - Our primary (in-depth) study took place on the Ambatolava inselberg of the Mt. Angavokely Forest Station located in the central highlands of Madagascar, $40 \mathrm{~km} \mathrm{SE}$ of Antananarivo $\left(18^{\circ} 55^{\prime} 4^{\prime \prime} \mathrm{S}, 47^{\circ} 43^{\prime} 9^{\prime \prime} \mathrm{E}\right)$. The site is managed by Direction Générale des Eaux et Forêts. Over the past twenty years, significant orchid related research has occurred at Mt. Angavokely (Nilsson \& Rabakonandrianina 1988, Nilsson et al. 1992, Pettersson \& Nilsson 1993, Kluge et al. 1998, Kluge $\&$ Brulfert 2000), in part because of the presence of high orchid diversity with 101 species and 22 genera identified (Ceplitis \& Broström 1998). The property is 695 ha in size, of which inselbergs with rupicolous shrubland vegetation comprise 110 ha, plantations of non-native pine and eucalyptus comprise $435 \mathrm{ha}$, and a mix of moist sub-montane forest and schlerophyllous forests occur in the remaining area (estimate of 1949 aerial photograph, Ceplitis \& Broström 1998). The elevation ranges from $1,365 \mathrm{~m}$ to $1,770 \mathrm{~m}$. Annual precipitation ranges from $1,500 \mathrm{~mm}$ to $2,000 \mathrm{~mm}$, occurring 180 days of the year (Ceplitis \& Broström 1998), with fog as the primary source of moisture during the dry season that spans from April to October (Kluge \& Brulfert 2000).

The inselbergs of Madagascar have granite substrate, high levels of UV radiation and wind, temperature fluctuations, and thin nutrient poor soils
(Barthlott \& Porembski 1998, Fischer \& Theisen 2000, Porembski \& Barthlott 2000, Porembski et al. 2000). Inselbergs are often describe as 'biological islands' because their habitat characteristics and vegetation is exceptionally distinct from the surrounding landscape matrix (Porembski et al. 2000). The vegetation is dominated by species such as Helichrysum spp. and Senecio spp. (Asteraceae); Kalanchoe synsepala Baker (Crassulaceae); Coleochloa setifera (Ridl.) Gilly (Cyperaceae); Aloe capitata Baker (Liliaceae); Angraecum sororium Schltr. (Orchidaceae); Nematostylis anthophylla A. Rich. (Rubiaceae); Xerophyta dasyliriodes Baker (Velloziaceae); and various specis of moss, lichen, cyanobacteria, carnivorous plants, and ferns (Barthlott \& Porembski 1998, Fischer \& Theisen 2000, Kluge \& Brulfert 2000) (Fig. 1).

Fire History - Our study took place in 2004, three years after a fire that burned an estimated third of the Mt. Angavokely area. The timing allowed us to assess signs of species recovery or colonization post fire disturbance. We assessed fire history using historical site descriptions and photographs (Nilsson \& Rabakonandrianina 1988, Nilsson et al. 1992, Pettersson \& Nilsson 1993), and by interviewing local residents and elders of the neighbouring villages of Ambohijafy and Ambohimiadona. Additional photographs, taken post-fire by J.J. Randriamanindry were also used as reference. Within the Mt. Angavokely forest area, we specifically researched the fire history of three of the largest inselbergs (Ambatolava, Ambatomisondrotra, Angavobe).

The first inselberg, Ambatolava, 1645m, had a fire that occurred in November 2001. The fire was believed to be human caused because it occurred during a period of political instability. Villagers may have used arson as a form of protest, or as an attempt to expand agropastoral fires during civil unrest (Bloesch 1999, Kull 2002). The intensity of the fire was also influenced by the surrounding plantations of pyrophytic Eucalyptus robusta Sm., Pinus patula Schltdl. and Cham., and Pinus khasya Royle ex Hook. f.. with a higher fuel load accumulation (dry needles, fallen leaves, and bark) than the neighboring sections of native forest. In addition, the fire was ignited towards the lower side of Ambatolava and resulted 

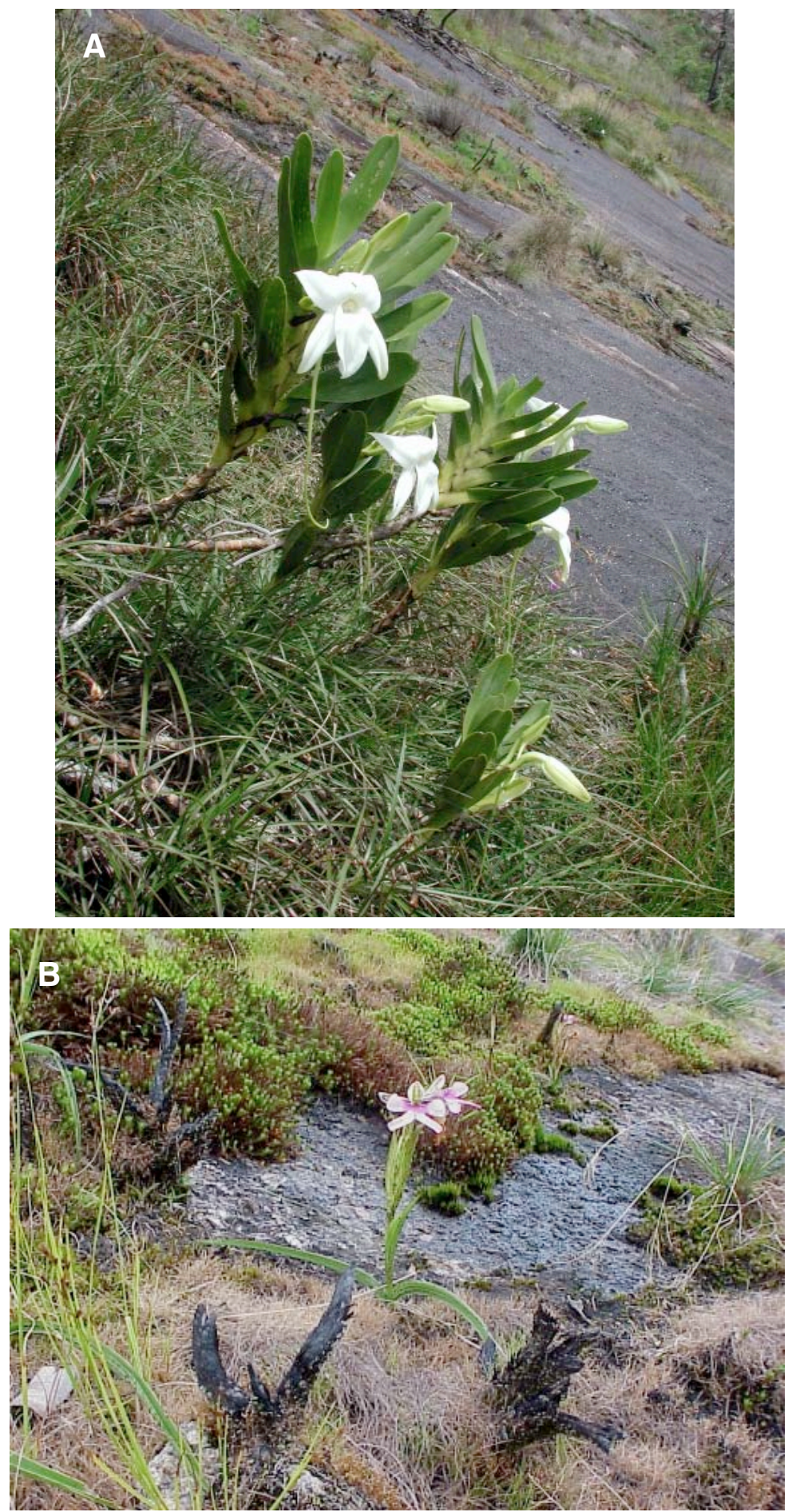

Figure 1. A. The orchid Angraecum sororium on an unburned vegetation mat in the foreground. Severely burned vegetation mats are neighboring in the background. Whitman, 2003. B. The orchid Cynorkis uniflora on a wet slope amongst charred vegetation remains. Randriamanindry, 2003. 
in an uphill burn pattern of higher intensity (Bloesch 1999) in contrast to lightning based fires (ignition at the highest point) that tend to have a downhill burn pattern of reduced destructive potential. Prior to the 2001 fire, Ambatolava was noted for its high density of A. sororium (Nilsson \& Rabakonandrianina 1988).

The second inselberg, Ambatomisondrotra, 1650m, was the site of a high intensity fire that occurred in the early 1990's (also believed to be human caused). Prior reports noted that the area once had similar vegetation composition as the unburned regions of the Ambatolava inselberg (unpubl. data). The fire resulted in near complete removal of larger shrubs from the mid to upper portion of the inselberg. Ambatomisondrotra had a more uniform burn pattern than Ambatolava because of the steepness of the slope (Bloesch 1999) and from observations of the site shortly after the event (Randriamanindry, pers. comm. 2004).

The third inselberg Angavobe, $1755 \mathrm{~m}$, was a site with unique cultural significant that influenced the fire regime history. Local villagers described social fady, a taboo based belief system, that discouraged people from setting fire to the forest because of the presence of royal tombs (featuring pre and post Christianity stylization) and sacrificial stones (Randriamanindry, pers. comm. 2004). The oldest tomb was associated with Andrianajavonana, "the noble who disappeared" a Merina king of the Central Highlands estimated to be from the $14^{\text {th }}$ century (Randriamanindry, pers. comm. 2004). Commoners were socially prohibited from harming the forest on Angavobe nearest the tombs because it was considered to be property of royalty even after death (Randriamanindry, pers. comm. 2004). A secondary social incentive was reinforced in the 1800 's during the reign of Queen Ranavalona I when the Angavobe caves were used as refuge from slavery and religious prosecution (Randriamanindry, pers. comm. 2004). This social belief system created small protected areas of native vegetation where lightning, but not human based fires, have existed for generations.

General Orchid Survey - We conducted a rapid biodiversity assessment of orchid occurrence (presence or absence of species) at the Ambatolava, Angavobe, and Ambatomisondrotra inselbergs, and a more indepth survey of orchid abundance specifically at Ambatolava. Plants were photographed and identified to genus or species in the field. No plants were taken from the site or harmed due to the endangered status of many endemic orchids. Species lists and images were then compared to botanical inventories conducted by the University of Antananarivo, Madagascar; Uppsala University, Sweden (Ceplitis \& Broström1998); the Missouri Botanical Gardens W ${ }^{3}$ TROPICOS database; and species descriptions by Perrier (1939 \& 1941), Du Puy et al. (1999), Hermans et al. (2007), and Cribb \& Hermans (2010).

Patterns of OrchidDiversity. - For the larger-scale portion of this study we compared the species present on all the three inselbergs ( $\gamma$-diversity), per inselberg ( $\alpha$-diversity), and between inselbergs ( $\beta$-diversity), using data from the general orchid survey. We were especially interested in the beta-diversity measures of species turnover between sites (Ambatolava, Ambatomisondrotra, and Angavobe) that were similar in elevation range, climate, geological history, and that shared a regional species pool, yet possessed differing fire history. Our goal was to gain a preliminary understanding of how gradients of historical habitat disturbance, rather than elevation (Jacquemyn et al. 2005), might influence the distribution patterns of orchids. The inselbergs (going east to west) were arranged: Angavobe to Ambatomisondrotra to Ambatolava, and ran roughly in a line $5 \mathrm{~km}$ in length and separated by a minimum of $2 \mathrm{~km}$ from each other. We used three equations (Jaccard distance, Sørensen distance, and Simple Matching Coefficent) based on the applied recommendations for presence/absence data noted by Anderson et al. (2011). All indices used emphasized distance or dissimilarity between sites (value of 0 meaning identical species composition). The beta-diversity was calculated as follows: Jaccard distance $d_{\mathrm{J}}[1-a /(a+b+c)]$; Sørensen distance $d_{\mathrm{S}}=$ $[1-2 a /(2 a+b+c)]$; and Simple Matching Coefficient, $d_{\mathrm{SM}}=1-(a+e) /(a+b+c+e)$; where $a$ is a species presence at both sites (11), $b(10)$ or $c(01)$ is a species present at only one of the two sites, and $e(00)$ is a species missing from both sites but found within the greater area (Anderson et al. 2011).

In-depth Survey of Orchid Abundance. - For the site specific (more intensive) portion of this study we focused on the Ambatolava Inselberg, the only location with burn patterns that could be clearly evaluated in 
relation to a fire with a known occurrence date (2001). At the Ambatolava site we surveyed seven $50 \mathrm{~m} \mathrm{x}$ $2 \mathrm{~m}$ line transects located between $1460 \mathrm{~m}$ to $1645 \mathrm{~m}$ in elevation. We drew the transect lines across all accessible regions using a 50m survey tape, compass, and GPS (Garmin Geko 301). The line transects were a minimum distance of $75 \mathrm{~m}$ apart and ran horizontally from south to north on the central ridge or eastern slope (the western side was inaccessible). Within $1 \mathrm{~m}$ on either side of the transect line per vegetation mat we counted the number of orchids present based on distinct above ground growth, rather than the number of canes, stems, or underground growth. We defined a vegetation mat in a generalized manner that included monocotyledonous mats dominated by $C$. setifera or $X$. dasyliriodes, ephemeral flush vegetation, moss cushions, or charred humus or vegetation remains (Barthlott \& Porembski 1998, Fischer \& Theisen 2000, Kluge \& Brulfert 2000, Porembski \& Barthlott 2000, Porembski et al. 2000).

We identified flowering species along the transect lines and categorized all orchids as lithophytic (epilithic) or terrestrial. Lithophytic orchids are found primarily on granite (or occasionally as epiphytes), and are slow growing with drought tolerant waxy leaves and aerial roots. Many lithophytic species in Madagascar are associated with the subtribe Angraecinae (species such as Angraecum sororium or Jumellea rigida Schltr.) or from the subtribe Aerangidinae with species such as Aerangis ellisii (B.S. Williams) Schltr.. Terrestrial orchids are also found on inselbergs and occasionally grasslands, with tuberous roots and periods of underground dormancy during the dry season. Many terrestrial orchids are from the subtribe Habenariinae (such as Cynorkis uniflora Lindl.) or Brownleeinae (such as Brownleea coerulea Harv. ex Lindl.).

Environmental Factors - We surveyed environmental factors that were hypothesised to play a significant role in the micro-site distribution patterns of orchids. The first environmental factor we examined in the field was based on the impact of fire, categorized by severity and defined as:

- Non-burned: areas with no signs of fire or significant heat damage;

- Minor to moderate: areas with a mosaic of heat or fire damage to no more than two thirds of the vegetation, upper branches of plants may have had some heat damage or fire effects but little to no signs of ground level fire;

- Severe: majority of the pre-fire vegetation charred or dead with signs of high heat intensity and fire effects at ground level.

The second factor examined was the influence of moisture availability (separate from water acquired directly from precipitation, fog, or dew accumulation on leaves) defined as:

- Wet: areas with continuous water seepage, dark granite slick from moisture saturation and cyanobacteria, with thick layers of moss or ephemeral flush vegetation (Barthlott \& Porembski, 1998; Porembski et al. 2000; Fischer \& Theisen, 2000).

- Dry: areas with no sign of water seepage, dry soil, and granite above and below the vegetation mat light in color.

Statistical Analyses - We analyzed the evenness of vegetation mat categories (combinations of fire severity and moisture availability) using a two by three contingency table. The relationship between orchid density per $\mathrm{m}^{2}$ and fire severity (non-burned, minormoderate, and severe) was analyzed using a nonparametric Kruskal-Wallis test; moisture availability (with or without presence of seasonal water seepage) was analyzed using a two-sample Wilcoxon test. We analyzed the number of orchids in relation to the size of non-burned vegetation mats with linear regression, if there was a significant positive relationship then a pre-fire population estimate would be made. Next, we analyzed the interspecies interaction for orchids in all areas using linear correlation. Lastly, we described the spatial distribution (random, even, or clumped) using the Index of Dispersion and Index of Clumping. All analyses were specific to species, genus, or subtribe depending on the sample size and evenness between groups. All statistical analyses had $\alpha=0.05$ and were performed with R software version 2.3.1 (www.r-project.org).

\section{Results}

General Orchid Survey - A total of seventeen orchid species from seven genera and six subtribes (plus two unusual white morphs) were found on one or more of 
TABLE 1. General survey of orchid presence and absence on three inselbergs at the Mt. Angavokely Forest Station.

\begin{tabular}{|c|c|c|c|c|}
\hline & & Angavobe & Ambatolava & Ambatomisodrotra \\
\hline Aerangidinae & Aerangis ellisii & $\mathrm{X}$ & $\mathrm{x}$ & \\
\hline Angraecinae & Angraecum sororium & $\mathrm{X}$ & $\mathrm{X}$ & $\mathrm{X}$ \\
\hline Angraecinae & Jumellea maxillarioides & $x$ & & \\
\hline Angraecinae & Jumellea rigida & & $\mathrm{X}$ & $\mathrm{X}$ \\
\hline Brownleeinae & Brownlea coerulea & $\mathrm{X}$ & & \\
\hline Bulbophyllinae & Bulbophyllum sp. 1 & $\mathrm{X}$ & & \\
\hline Habenariinae & Cynorkis angustipetala & & $\mathrm{X}$ & \\
\hline Habenariinae & Cynorkis baronii & & & $\mathrm{X}$ \\
\hline Habenariinae & Cynorkis coccinelloides & & & $\mathrm{X}$ \\
\hline Habenariinae & Cynorkis fastigiata & $\mathrm{X}$ & $\mathrm{X}$ & $\mathrm{X}$ \\
\hline Habenariinae & Cynorkis gibbosa & $\mathrm{X}$ & & $\mathrm{X}$ \\
\hline Habenariinae & Cynorkis gibbosa* & $\mathrm{X}$ & & \\
\hline$\underline{\text { Habenariinae }}$ & Cynorkis lilacina & & $\mathrm{x}$ & \\
\hline Habenariinae & Cynorkis perrieri & $\mathrm{X}$ & & \\
\hline Habenariinae & Cynorkis uniflora & $\mathrm{X}$ & $\mathrm{X}$ & $\mathrm{X}$ \\
\hline Habenariinae & Cynorkis uniflora* & $\mathrm{X}$ & & \\
\hline Habenariinae & Cynorkis sp. 1 & $\mathrm{X}$ & & \\
\hline Habenariinae & Cynorkis sp. 2 & & & $\mathrm{x}$ \\
\hline Polystachyeae & Polystachya rosea & $\mathrm{X}$ & & \\
\hline
\end{tabular}

* Unusual white flower morph

the inselbergs surveyed (Table $1 \& 2$ ). The orchids present were estimated to represent $17 \%$ of the overall Orchidaceae diversity across all habitats of the greater Mt. Angavokely area (Ceplitis \& Broström1998), and represented 17 out of $33(51 \%)$ of the inselberg specific species found in Madagascar (Fischer \& Theisen 2000). The most common orchids encountered at all three inselbergs included Cynorkis fastigiata Thouars, Cynorkis uniflora, and Angraecum sororium. Some species were found at two locations, such Aerangis ellisii, Cynorkis gibbosa Ridl., and Jumellea rigida. However, a total of eleven orchids (65\%) were restricted to a single site (Table $1 \& 2$ ).

The Ambatolava inselberg was the only site with Cynorkis angustipetala Ridl., Cynorkis lilacina Ridl., and an unidentified Cynorkis sp. Thouars.. Ambatomisondrotra was the only site with Cynorkis baronii Rolfe, or Cynorkis coccinelloides Schltr., and was unique in that it was also the site of the largest colony of $C$. uniflora noted. We also observed a distinct absence of Angraecinae species (including seedlings) from the entire upper region of the inselberg that had been burned; the exception being a J. rigida near the unburned forest edge. Angavobe, the area with lightning but not human associated fires, had the highest diversity of orchids unique to a single site, including Brownleea coerulea, unidentified Bulbophyllum sp. Thouars, Cynorkis perrieri Schltr., unidentified Cynorkis sp. Thouars, Jumellea maxillarioides (Ridl.) Schltr., Polystachya rosea Ridl. and unusual white morphs of Cynorkis gibbosa Ridl. and Cynorkis uniflora Lindl.. Angavobe was notable as the location with the most massive $A$. sororium surveyed with individual canes $>4 \mathrm{~m}$ in length (max. height of $1.5 \mathrm{~m}$ noted elsewhere) and with $>250$ nodes present that typically mark annual growth (one pair of leaves per year). We estimated the largest $A$. sororium (individual or colony) at Angavobe to be hundreds of years old.

Patterns of Orchid Diversity - The transition of species diversity ( $\beta$-diversity) using Jaccard distance $\left(d_{\mathrm{J}}\right)$, Sørensen distance $\left(d_{\mathrm{S}}\right)$, and Simple Matching Coefficient $\left(d_{\mathrm{SM}}\right)$ was estimated for paired site combinations. Each individual inselberg was represented by a single letter as follows: Ambatolava (L) - burned 2001, Ambatomisondrotra (M) - burned 1990 's, and Angavobe (G) -human fires absent. The 
TABLE 2. Patterns of orchid diversity on inselbergs.

Unique occurrence count

\begin{tabular}{|c|c|c|c|c|}
\hline \multicolumn{2}{|c|}{ Total Diversity of Inselbergs Surveyed } & SUBTRIBE & GENUS & SPECIES \\
\hline \multicolumn{2}{|c|}{$\begin{array}{l}\text { Combined list of all species found on the three inselbergs, Angavobe, } \\
\text { Ambatolava, and Ambatomisondrotra }\end{array}$} & 6 & 7 & 17 \\
\hline Diversity per Inselberg & Fire History & SUBTRIBE & GENUS & SPECIES \\
\hline Total for Angavobe & Absence of human associated fires & 6 & 7 & 11 \\
\hline Total for Ambatomisondrotra & Human associated fire in 1990's & 2 & 3 & 8 \\
\hline Total for Ambatolava & Human associated fire in 2001 & 3 & 4 & 7 \\
\hline
\end{tabular}

Orchid Distribution, Patterns of Overlap or Isolation

\begin{tabular}{ll|c|c|c|c}
\hline Description & Distribution & Code & SUBTRIBE & GENUS & SPECIES \\
\hline Widespread & Angavobe, Ambatolava, \& Ambatomisodrotra & GLM & 2 & 3 & 3 \\
\hline Variable & Angavobe \& Ambatolava & GL & 1 & 1 & 1 \\
\hline Variable & Angavobe \& Ambatomisodrotra & GM & 0 & 0 & 1 \\
\hline Variable & Ambatolava \& Ambatomisodrotra & LM & 0 & 0 & 1 \\
\hline Site specific & Angavobe only & G & 3 & 3 & 6 \\
\hline Site specific & Ambatolava only & L & 0 & 0 & 2 \\
\hline Site specific & Ambatomisondrotra only & M & 0 & 0 & 3 \\
\hline
\end{tabular}

results are summarized as: $\mathrm{L} \& \mathrm{M}-\left(d_{\mathrm{J}}=0.64, d_{\mathrm{S}}=\right.$ $\left.0.47, d_{\mathrm{SM}}=0.41\right), \mathrm{L} \& \mathrm{G}\left(d_{\mathrm{J}}=0.71, d_{\mathrm{S}}=0.56, d_{\mathrm{SM}}=\right.$ $0.59)$, and $\mathrm{M} \& \mathrm{G}\left(d_{\mathrm{J}}=0.73, d_{\mathrm{S}}=0.58, d_{\mathrm{SM}}=0.65\right)$. All indices revealed a similar trend; paired burned sites $(\mathrm{L}$ $\& \mathrm{M})$ had a lower $\beta$-diversity distance score (reduced turnover and greater similarity of species present) than pairing of inselbergs with burned and nonburned fire history. The inclusion of information on species absence (relative to $\gamma$-diversity) resulted in the greatest dissimilarity between inselberg combinations as noted with the Matching Coefficient $\left(d_{\mathrm{SM} \max }-d_{\mathrm{SM}}\right.$ $\left.\min _{\min }=0.24\right)$, compared to Jaccard distance $\left(d_{\mathrm{J} \max }-d_{\mathrm{J} \min }\right.$ $=0.10)$ and Sørensen distance $\left(d_{\mathrm{S} \max }-d_{\mathrm{S} \min }=0.11\right)$ that emphasized joint species presence. Joint absences also revealed that the combined species diversity for burned sites (Ambatolava and Ambatomisondrotra) was missing six out of the seventeen possible inselberg orchids surveyed from the larger area $(30 \%$ of the $\gamma$-diversity).

In-depth Survey of Orchid Abundance - At Ambatolava, we surveyed $700 \mathrm{~m}^{2}$, and counted 45 vegetation mats totaling $450.7 \mathrm{~m}^{2}$. The vegetation mats varied greatly in shape, size $\left(5.35 \mathrm{~m}^{2} \pm \mathrm{SE} 0.83\right)$ and distance $\left(2.65 \mathrm{~m}^{2} \pm \mathrm{SE} 0.74\right)$ from each other edge to edge. We counted a total of 45 lithophytic orchids from the subtribe Angraecinae (36 A. sororium and nine Jumellea rigida) and 310 terrestrial orchids from the subtribe Habenariinae (one Cynorkis angustipetala Ridl., 52 C. fastigiata Thou., and 257 C. uniflora). All species were endemic to Madagascar, except for C. fastigiata, a species indigenous to Madagascar, Comoros, the Mascarenes, and Seychelles (Perrier $1939 \& 1941)$. Both subtribes were present at an equal number of sites (fourteen out of forty five vegetation mats), but the distribution by individual species was unpredictable. Some orchids were relatively abundant, but restricted to a limited number of locations (such as $C$. uniflora with 257 individuals at eight sites). We then found it necessary to group the orchids together by subtribe for a more even comparison of the taxa.

Environmental Factors - We categorized 15 of the vegetation mats as non-burned $\left(118 \mathrm{~m}^{2}=26 \%\right), 11$ with minor to moderate fire damage $\left(113 \mathrm{~m}^{2}=25 \%\right)$, and $19\left(219.70^{2}=49 \%\right)$ as having severe fire damage. Non-burned and severely burned vegetation mats were observed directly neighboring each other. The moisture of the slopes also varied, 25 mats $\left(285.8 \mathrm{~m}^{2}=63 \%\right)$ ranged from being damp to having continuous water seepage, and the other 20 mats $\left(164.90 \mathrm{~m}^{2}=36 \%\right)$ were extremely dry. The $2 \times 3$ contingency table analysis 
showed a significant difference in the evenness of the fire/moisture combinations of vegetation mat categories (Pearson's Chi Square $=8.246, \mathrm{p}=0.016$ ), but there was no clear pattern to predict which areas would be burned (wet with severe fire damage was the most common combination). However, other factors might have influenced fire patterns such as wind exposure, steepness of slope, or distance to the plantation tree line. Vegetation mats that were the least impacted by fire were in depressions or fissures in the rock; sheltered from wind; or were isolated from each other.

Orchid Response to Environmental Factors - For the lithophytic Angraecinae orchids, fire severity was highly significant Fig 1. A. (all species, KruskalWallace chi-squared 18.6445, df $=2, \mathrm{p}$-value $=$ $<0.001 ;$ A. sororium, Kruskal-Wallace chi-squared 19.025, df $=2$, p-value $=<0.001$ ) There was no significant relationship between orchid density and moisture availability by subgroup or by species. The orchids had the highest density $\left(0.32\right.$ per $\mathrm{m}^{2}$, equal to $84 \%$ of those surveyed) in unburned areas, followed by $\left(0.06\right.$ per $\mathrm{m}^{2}$, equal to $16 \%$ of those surveyed) in minor to moderately burned areas, and no individuals in severely burned areas. The significant results for the terrestrial Habenariinae were opposite from that of the lithophytic Angraecineae. Fire was not significant, yet moisture availability was highly significant Fig 1 . B. (all species, Wilcox rank sum, $w=149$, $p$-value $=$ 0.005 ; C. uniflora, Wilcox rank sum, $\mathrm{w}=170$, $\mathrm{p}$-value $=0.006)$. The exception to the Habenariinae trend was $C$. fastigata, which was not sensitive to moisture availability, but was to fire (Kruskal-Wallis chisquared $=8.210, \mathrm{df}=2, \mathrm{p}$-value $=0.016)$. Terrestrial Habenariinae orchids had the highest density average (1.1 per $\mathrm{m}^{2}$, equal to $99 \%$ of those surveyed) in wet areas, including locations with severe fire damage. Species level analyses were non-significant for the least common of the orchids surveyed, C. angustipetala (Habenariinae) and $J$. rigida (Angraecinae).

Orchid Distribution - Angraecinae had a significant relationship between the number of orchids and the size of a non-burned vegetation mat (adjusted $\mathrm{R}^{2}=$ 0.473 , $p$-value $=0.003, n=15$ ), but Habenariinae did not, even in wet non-burned areas. Prefire population estimates were made for Angraecinae (but could not be made for Habenariinae) based on the linear equation (number of orchids $=0.251 *$ mat size + 0.562). We estimated that $67 \%$ of the lithophytic Angraecinae orchids at Ambatolava perished during the 2001 fire.

There was no significant interaction between the two orchid subtribes (Angraecinae and Habenariinae); including results from a post-hoc analysis of positive environmental factors (non-burned sites, wet sites, and non-burned wet sites). There was a positive association between $A$. sororium and C. fastigata (Kendall's Rank Correlation, tau $=0.590, \mathrm{p}$-value $=$ $<0.001$ ) and to a lesser extent between A. sororium and $J$. rigida (Kendall's Rank Correlation, tau $=0.273$ , $\mathrm{p}$-value $=0.049$ ). Angraecinae had a uniform pattern of distribution (Index of Dispersion $=0.436$, Index of Clumping $=-0.564$ ) with the highest density in nonburned areas. Habenariinae had a clumped pattern of distribution (Index of Dispersion $=8.711$, Index of Clumping $=7.711$ ) with the highest density in wet areas.

\section{Discussion}

General Orchid Survey - The diversity of endemic orchids on inselbergs, and the vulnerability of some species to anthropogenic disturbance, reinforces the conservation importance of this unique habitat type. The most compelling observation from the general orchid survey was the higher biodiversity at Angavobe, a site with lightning based fires but absence of anthropogenic fires, compared to Ambatomisondrotra (fire in 1990's) or Ambatolava (fire in 2001). Angavobe was also the site with the highest number of species (six) and genera (three) restricted to a single site. One concern for the future is whether or not Angavobe will continue to be regarded as an important cultural site, or if the traditional knowledge of restricted burning near tombs and sacrificial stones will be lost with the passing of generations or the immigration of individuals from different regions who are unaware of this social fady. Additional conservation protection of the Angavobe inselberg, ideally in partnership with neighboring villagers, environmental organizations, and regional land managers, is highly recommended.

Spatial Patterns of Orchid Diversity - We found that sites with a shared history of fire disturbance (Ambatomisondrotra and Ambatolava) had species composition more similar to each other than 
combinations with differing fire history regardless of spatial orientation; a pattern most noticeable when factoring in joint-absences of species (Matching Coefficent). Our average Sørensen distance (0.53) was more similar to the average value $(0.5)$ noted on African (Cameroon, Gabon, Guinea) inselbergs across a range of plant formations (Parmentier et al. 2005), than the beta-diversity of orchids (0.25) observed across elevational gradients on the neighboring island of Réunion (Jacquemyn et al. 2005), suggesting that our results may be more of a reflection of inselberg plant communities than patterns specific to orchids. A larger scale analysis of Malagasy orchid betadiversity, especially in relation to gradients of habitat disturbance, is recommended for the future.

Orchid Response to Environmental Factors Lithophytic Angraecinae orchids were fire sensitive and were interpreted to rely on other adaptations to successfully tolerate temperature and moisture fluxuations and to compete against dominant inselberg vegetation such as $X$. dasyliriodes or $A$. capitata. Angraecinae survival adaptations include environmental stress tolerance (Kluge et al. 1998, Kluge \& Brulfert 2000), year round photosynthesis, and the ability to grow taller than neighboring shrubs or forbs to compete for resources. Inter and intraspecific competition may explain the uniform distribution pattern noted.

We were surprised that Angraecinae orchids were so sensitive to heat damage given that Porembski \& Barthlott (2000) noted that some drought tolerant monocots were protected from fire by the dense growth of leaves and roots covering the pseudostem. However we did observe that $A$. sororium had more signs of heat damage than fleshy succulents (ie Aloe capitata) of similar height in the same area. Post-fire regeneration by $A$. sororium in areas of moderate fire damage was only noted at the center of exceptionally large orchid patches. Angraecinae orchids may be more vulnerable to fire due to their year round foliage, aerial roots, and tolerance for the driest slopes. They also tend to acquire a thick cushion of moss, leaves, and organic material around their base (Kluge \& Brulfert 2000) that helps to hold moisture, but may also increases the available fuel biomass (intensity of fire) per vegetation mat.
An important conservation question raised by this study is: "how long will it take for Angraecinae to recover from human associated fire damage?" Populations may be resilient against disturbance events by the longevity of reproductively successful individuals, but only if the habitat conditions remain suitable for their offspring and enough unique individuals remain to prevent a genetic bottleneck. The largest Angraecinae observed flowering (A. sororium) was interpreted to be very long lived (multi-decade, or even multi-century at Angavobe), an age span consistent with other inselberg species (Porembski \& Barthlott 2000). However no Angraecinae seedlings were found repopulating burned mats three years or even $>10$ years post-fire despite the relatively high availability of seed sources from multiple individuals within the area (unpubl. data). Inhibited establishment of seedlings post-fire has also been described for other non mat-forming inselberg species (Porembski \& Barthlott 2000) and is a threat to endemic flora as the rate of human caused fires increases. For future studies it would be useful to gain a more expansive and long-term (multi-generational) understanding of metapopulation dynamics of Angraecinae orchids, especially compared to Habenariinae, to establish a stronger estimate of recovery time post-disturbance.

The terrestrial Habenariinae orchids of our study were limited primarily by their micro-habitat preference for wet slopes rather than by fire. Prior studies of $C$. uniflora also noted the highest orchid abundance in locations with continuous or ephemeral water seepage (Nilsson et al. 1992, Fischer \& Theisen $2000)$. The smaller size $(10-30 \mathrm{~cm})$, lack of water storing fleshy leaves or pseudobulbs, and the rapid season-specific growth of these orchids may explain their moisture dependency. Future studies that include other environmental factors found to be significant for inselberg flora, such as soil $\mathrm{pH}$, depth, or distance to native forest (Parmentier 2003), might explain why Habenariinae orchids displayed such clumped patterns of distribution and abundance independent from vegetation mat size or co-occurrence of Angraecinae species.

The enigmatic orchid of this study was $C$. fastigiata, with habitat preferences similar to $A$. sororium. One possible explanation is that both orchids share similar mycorrhizal fungi preferences 
for germination; or that $C$. fastigiata fills a different habitat or successional niche than $C$. uniflora or $C$. angustipetala. This result raises the debate as to whether species should be grouped together based on phylogenetic similarity or by habitat needs.

Within Madagascar, it has been noted that Habenariinae orchids (genus Cynorkis and Habenaria) and similar terrestrial orchids of various other subtribes (genus Liparis, Eulophia, Benthamia, Lissochilus, Disa, Satyrium) benefit from occasional fires and sustainable disturbance that create "orchid meadows" with reduced interspecies competition (Rabetaliana et al. 1999, Bloesch et al. 2002). This trend has also been described globally for terrestrial orchids in locations such as Australia (Yates et al. 2003), and South Africa (Linder et al. 2005), with some pyrogenic orchids (such as Cyanicula ashbyae Hopper and A.P.Br.) only flowering within the first year post-fire (Yates et al. 2003). Fire may be less of a threat to Habenariinae orchids because of their tuberous roots, underground dormancy during the dry season, and tolerance of thinner topsoil that can occur after burning and erosion.

A different question raised by this study is: "why did the two orchid subtribes have different survival strategies, or ecological niches, within a shared habitat if their distribution was independent from each other?" One explanation is that when fire occurs, it creates an irregular mosaic-like pattern of fire disturbance, allowing for different stages of succession per vegetation mat with reduced competition for resources. Another perspective is that inselbergs might support both equilibrium and nonequilibrium based plant communities within a small spatial scale and that the differences between orchid subtribes are a reflection of larger species composition trends. Angraecinae might be considered to be a part of an equilibrium (or late-successional) based community, influenced by biotic competition year round; whereas Habenariinae might be within a nonequilibrium, ephemeral flush vegetation community heavily influenced by abiotic conditions or stochastic disturbances (Porembski et al. 2000).

Conclusion. From this study it can be concluded that it is inappropriate to assume that all species of inselberg Orchidaceae have the same response to fire or habitat moisture requirements. Lithophytic Angraecinae were sensitive to fire, but tolerant of limited moisture availability, and had a uniform pattern of distribution. In contrast, terrestrial Habenariinae were not as affected by fire but were limited to slopes with high water seepage and had a clumped pattern of distribution. Lithophytic Angraecinae orchids are considered to be at risk and an increase in the frequency or severity of fire may negatively affect sustainable population sizes. Further conservation of inselberg habitat and its unique flora is strongly recommended.

Acknowledgements. Special thanks to David Mason and Fairhaven College for the Adventure Learning Grant; the Northwest Orchid Society; Seacology; University of Antananarivo; Direction Générale des Eaux et Forêts; Kathryn Anderson, John Bower, Robin Matthews, and John McLaughlin of Western Washington University; Zachary Rogers and the Missouri Botanical Gardens; Nivo Raharison; and Urs Bloesch, L. Anders Nilsson, Ingrid Parmentier, and Nathan G. Swenson for feedback. Additional thanks to Lankesteriana reviewers, and anonymous feedback received at the $18^{\text {th }}$ World Orchid Conference (Dijon, France) and the Sigma Xi Conference (Seattle, U.S.A). In Memoriam of Joyce Stewart (1936 2011) and her advocacy of Angraecoid orchid conservation.

\section{Literature Cited}

Anderson, M.J., T.O. Crist, J.M. Chase, M. Vellend, B.D. Inouye, A.L. Freestone, N.J. Sanders, H.V. Cornell, L.S. Comita, K.F. Davies, S.P. Harrison, N.J.B. Kraft, J.C. Stegen \& N.G. Swenson. 2011. Navigating the multiple meanings of beta diversity: a roadmap for the practicing ecologist. Ecol. Lett. 14: 19-28.

Barthlott, W. \& S. Porembski. 1998. Diversity and phytogeographical affinities of Inselberg vegetation in tropical Africa and Madagascar. Pp. 119-129 in: C.R. Huxley, J.M. Lock \& D.F. Cutler (eds.), Chorology, taxonomy and ecology of the floras of Africa and Madagascar. Kew, Kew Publishing.

Bloesch 1999. Fire as a tool in the management of a savanna/dry forest reserve in Madagascar. Appl. Veg. Sci. 2: 117-124.

Bloesch, U., Bosshard, A.P. Shachenmann, H. Rabetaliana \& F. Klötzli. 2002. Biodiversity of the subalpine forest-grassland ecotone of the Andringitra Massif, 
Madagascar. Pp. 165-175 in: C. Körner \& E.M. Spehn (eds.), Mountain biodiversity- a global assessment. London, Parthenon Publishing.

Bosser, J.M., Du Puy, D.J. \& P. Phillipson. 1996. Madagascar and surrounding islands. Pp. 103-107 in: IUCN/SSC Orchid Specialist Group; Status Survey and Conservation Action Plan - Orchids. IUCN Switzerland and UK.

Burney, D.A., G.S. Robinson \& L.P. Burney. 2003. Sporomiella and the late Holocene extinctions in Madagascar. P Natl. Acad. Sci. 100: 10800-10805.

Ceplitis, A. \& A. Broström. 1998. Vascular plant diversity in a mountain rainforest at Station Forestière d'Angavokely, Madagascar. Minor field study report 039. Uppsalla, Committee for Tropical Ecology Uppsalla University.

Clarke, P.J. 2002. Habitat islands in fire-prone vegetation: do landscape features influence community composition? J. Biogeogr. 29: 677-684.

Cribb, P.J. \& J. Hermans. 2010. Field guide to the orchids of Madagascar. Kew, Kew Publishing.

De La Bathie, H.P. 1939, 1941. Flora of Madagascar, 49th Family - Orchids. Paris, France. Translated by S. Beckman. 1981. Volume I and II combined. Lodi, California.

Du Puy, D. \& J.F. Moat. 1998. Vegetation mapping and classification in Madagascar (using GIS): implications and recommendations for the conservation of biodiversity. Pp 97 -117 in: C.R. Huxley, J.M. Lock, \& D.F. Culter (eds.), Chronology, taxonomy and ecology of the floras of Africa and Madagascar. Kew, Kew Publishing.

Du Puy, D., P.J. Cribb, J. Bosser, J. Hermans \& C. Hermans. 1999. The Orchids of Madagascar. First edition. Kew, Royal Botanical Gardens.

Fischer, E. \& I. Theisen. 2000. Vegetation of Malagasy inselbergs. Pp. 259-276 in: S. Porembski \& W. Barthlott (eds.), Inselbergs biotic diversity of isolated rock outcrops in tropical and temperate Regions. Berlin, Springer-Verlag.

Jacquemyn, H., C. Micheneau, D.L. Roberts \& T. Pailler. 2005. Elevation gradients of species diversity, breeding system and floral traits of orchid species on Réunion Island. J. Biogeogr. 32: 1751-1761.

Klein, J. 2004. Fiddling while Madagascar burns. Deforestation discourses and highland history. Norw. J. Geog. 58: 11-22.

Kluge, M., B.Vinson \& H. Ziegler. 1998. Ecophysiological studies on orchids of Madagascar: incidence and plasticity of crassulacean acid metabolism in species of the genus Angraecum Bory. Plant Ecol. 135: 43-57.

Kluge, M \& J. Brulfert. 2000. Modes of photosynthesis in plants of Mt. Angavokely (Central High Plateau of Madagascar). Pp. 161-174 in: S. Porembski and W. Barthlott (eds.), Inselbergs biotic diversity of isolated rock outcrops in tropical and temperate regions. Berlin, Springer-Verlag.

Kull, C.A. 2000. Deforestation, erosion, and fire: degradation myths in the environmental history of Madagascar. Environ. Hist. 6: 423-450.

Kull, C.A. 2002. Madagascar aflame: landscape burning as peasant protest, resistance, or a resource management tool? Pol. Geogr. 21: 927-953.

Kremen, C., A. Cameron, A. Moilanen, S.J. Philips, C.D. Thomas, H. Beentje, J. Dransfield, B.L. Fischer, F. Glaw, T.C. Good, G.J. Harper, R.J. Hijams, D.C. Lees, E. Louis Jr., R.A. Nussbaum, C.J. Raxworthy, A. Razafimpahanana, G.E. Schatz, M. Vences, D.R. Vieties, P.C. Wright \& M.L. Zjhra. 2008. Aligning conservation priorities across taxa in Madagscar with High-Resolution Planning Tools. Science 320: 222-226.

Harper, G.J., M.K. Steininger, C.J. Tucker, D. Juhn \& F. Hawkins. 2007. Fifty years of deforestation and forest fragmentation in Madagascar. Environmental Conservation 34: 325-333.

Hopper, S.D. 2000. Creation of conservation reserves and managing fire on granite outcrops - a case of study of Chiddarcooping Nature Reserve in Western Australian wheatbelt. J. Roy. Soc. W. Aust. 83: 173-186.

Hermans, J., C. Hermans, D. du Puy, P.J. Cribb \& J. Bosser. 2007. Orchids of Madagascar. Second edition. Kew, Kew Publishing.

Leader-Williams, N \& H.T. Dublin. 2000. Charismatic megafauna as 'flagship species'. Pp 53-81 in: A. Entwistle \& N. Dunstone (eds.), Priorities for the Conservation of Mammalian Diversity: Has the Panda Had its Day? Cambridge, Cambridge University Press.

Linder, H.P., H. Kurzweil \& S.D. Johnson. 2005. The Southern African orchid flora: composition, sources and endemism. J. Biogeogr. 32: 29-47.

Myers, N., Mittermeier, R.A., Mittermeier, C.G., da Fonseca, G.A.B \& J. Kent. 2000. Biodiversity hotspots for conservation priorities. Nature. 403: 853 - 858 .

Nilsson, L.A. \& E. Rabakonandrianina. 1988. Hawk-moth scale analysis and pollination specialization in the epilithic Malagasy endemic Aerangis ellisii (Reichenb. fil.) Schltr. (Orchidaceae.) Bot. J. Linn. Soc. 97: 49-61. 
Nilsson, L.A., E. Rabakonandrianina, R. Rotaharivelo \& J.J. Randriamanindry. 1992. Long pollinia on eyes: hawk-moth pollination of Cynorkis uniflora Lindley (Orchidaceae) in Madagascar. Bot. J. Linn. Soc.109: 145-160.

Parmentier, I. 2003. Study of the vegetation composition in three inselbergs from continental equatorial Guinea (western central Africa): effects of site, soil factors, and position relative to forest fringe. Belg. J. Bot. 136: 6372.

Pettersson, B. \& L.A. Nilsson. 1993. Floral variation and deceit pollination in Polystachya rosea (Orchidaceae) on an inselberg in Madagascar. Opera Bot. 121: 237245.

Porembski, S. \& W. Barthlott. 2000. Granitic and gneissic outcrops (Inselbergs) as centers of diversity for desic- cation-tolerant vascular plants. Plant Ecol. 151: 19-28.

Porembski, S., R. Seine \& W. Barthlott. 2000. Factors controlling species richness of Inselbergs. Pp. 451-481 in: S. Porembski and W. Barthlott (eds.), Inselbergs biotic diversity of isolated rock outcrops in tropical and temperate regions. Berlin, Springer-Verlag.

Rabetaliana, H., M. Randriambololona \& P. Schachenmann. 1999. The Andringitra National Park in Madagascar. Unasylva 50: 25-30.

Raxworthy, C.J. \& R.A. Nussbaum. 1996. Montane amphibian and reptile communities in Madagascar. Conserv. Biol. 10: 750-756.

Yates, C.J., S.D. Hopper, A. Brown \& S. van Leeuwen. 2003. Impact of two wildfires on endemic granite outcrop vegetation in Western Australia. J. Veg. Sci. 14: $185-193$. 